\author{
PaWel Gata ${ }^{1}$
}

\title{
Ochrona bioróżnorodności a prawa własności intelektualnej w rolnictwie
}

\section{Wprowadzenie}

Pojęcie „bioróżnorodność”, a w zasadzie „różnorodność biologiczna” znalazło swoją definicję legalną w art. 2 Konwencji o różnorodności biologicznej, ${ }^{2}$ ogłoszonej i przyjętej w dniu 5 czerwca 1992 r. podczas międzynarodowej Konferencji Narodów Zjednoczonych na temat Środowiska i Rozwoju, ${ }^{3}$ która odbyła się w Rio de Janeiro.

Zgodnie z tą definicją: „różnorodność biologiczna oznacza zróżnicowanie wszystkich żywych organizmów pochodzących, inter alia, z ekosystemów lądowych, morskich i innych wodnych ekosystemów oraz zespołów ekologicznych, których są one częścią. Dotyczy to różnorodności w obrębie gatunku, pomiędzy gatunkami oraz ekosystemami"

Natomiast cele, jakie prawodawca międzynarodowy stawia przed ww. aktem praw określa art. 1 Konwencji, wskazując, że:

„Celami niniejszej konwencji, realizowanymi zgodnie z jej odpowiednimi postanowieniami, jest ochrona różnorodności biologicznej, zrównoważone użytkowanie jej elementów oraz uczciwy i sprawiedliwy podział korzyści wynikających z wykorzystywania zasobów genetycznych, w tym przez odpowiedni dostęp do zasobów genetycznych i odpowiedni transfer właściwych technologii, z uwzględnieniem wszystkich praw do tych zasobów i technologii, a także odpowiednie finansowanie."

W ścisłym związku z realizacji wskazanych wyżej celów Konwencji o bioróżnorodności pozostaje kolejna umowa międzynarodowa, a mianowicie Międzynarodowy traktat o zasobach genetycznych roślin dla wyżywienia i rolnictwa ${ }^{4}$ sporządzony

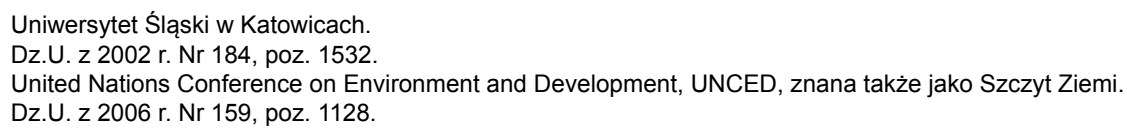


w Rzymie w dniu 3 listopada 2001 r. Zgodnie z art. 1 ust. 1.1. Międzynarodowego traktatu o zasobach genetycznych roślin dla wyżywienia i rolnictwa:

„Celami niniejszego traktatu jest ochrona i zrównoważone użytkowanie zasobów genetycznych roślin dla wyżywienia i rolnictwa oraz sprawiedliwy i równoprawny podział korzyści wynikających z ich użytkowania, które realizowane są zgodnie z Konwencją o różnorodności biologicznej, na rzecz zrównoważonego rolnictwa i bezpieczeństwa żywnościowego."

$\mathrm{W}$ aspekcie najbardziej istotnym, $\mathrm{z}$ punktu widzenia tematu niniejszego opracowania, tj. w zakresie wpływu regulacji prawnych dotyczących ochrony bioróżnorodności na zakres ochrony praw na dobrach niematerialnych w rolnictwie, kluczowe znaczenie ma jednak Protokół z Nagoi do Konwencji o różnorodności biologicznej dotyczący dostępu do zasobów genetycznych oraz uczciwego i sprawiedliwego podziału korzyści wynikających z ich wykorzystania przyjęty dnia 29 października 2010 r. oraz wdrażające jego postanowienia do porządku prawnego Unii Europejskiej Rozporządzenie Parlamentu Europejskiego i Rady (UE) nr 511/2014 z dnia 16 kwietnia 2014 r. w sprawie środków zapewniających zgodność użytkowników w Unii z wymogami wynikającymi z Protokołu z Nagoi dotyczącego dostępu do zasobów genetycznych oraz uczciwego i sprawiedliwego podziału korzyści wynikających z ich wykorzystania. ${ }^{5}$

Wskazane wyżej regulacje prawne wywierać będą w najbliższym czasie bezpośredni wpływ zarówno na proces tworzenia nowych dóbr niematerialnych w rolnictwie, jak i uzyskiwania ochrony takich dóbr oraz ich komercjalizacji.

\section{Prawa własności intelektualnej w rolnictwie}

Rozwój praw na dobrach niematerialnych, przejawiający się zarówno w procesie obejmowania ochroną dóbr, które dotychczas nie podlegały takiej ochronie, jak też polegający na udzielaniu praw na dobrach intelektualnych w coraz to większej liczbie krajów, objął także rolnictwo.

Dobrem niematerialnym, które uzyskało w ten sposób ochronę są odmiany roślin. Obecnie na świecie wyróżnić można w zasadzie dwa dominujące modele ochrony praw do odmian roślin. Są to: system ochrony patentowej oraz system sui generis wyłącznego prawa do odmiany.

W zakresie unormowań międzynarodowych problematyka ochrony praw do odmian roślin podlega trzem najistotniejszym grupom regulacji. Po pierwsze, źródłem prawa międzynarodowego, które odnosi się do problematyki ochrony wyłącznego prawa do odmian roślin jest Konwencja o ochronie nowych odmian roślin przyjęta 
podczas międzynarodowej konferencji, która odbywała się w Paryżu w dniach od 21 listopada do 2 grudnia 1961 r. ${ }^{6}$

Sygnatariusze Konwencji tworzą Związek Ochrony Nowych Odmian Roślin (art. 23 w związku z art. 1 pkt x) Konwencji), od nazwy którego Konwencja przyjęła nazwę Konwencji UPOV. ${ }^{7}$ Dotychczas Konwencja UPOV była trzykrotnie rewidowana, każdorazowo w Genewie w dniach: 10 listopada 1972 r., 23 października 1978 r. oraz 19 marca 1991 r.

Konwencja UPOV w swoim obecnym kształcie przyznaje hodowcy oraz jego następcom prawnym wyłączne prawo do dobra niematerialnego w postaci odmiany rośliny, a jednocześnie nakłada na swoich sygnatariuszy obowiązek wprowadzenia stosownych rozwiązań do wewnętrznych porządków prawnych. Konwencja nie tylko statuuje szczególne prawo do odmiany, ale zawiera również unormowania precyzujące jego zakres. Państwa członkowskie Konwencji UPOV (oraz Wspólnota Europejska) mają możliwość swobodnego kształtowania swoich porządków wewnętrznych, ważne jest jednak, aby rozwiązania prawne wprowadzone do systemów krajowych gwarantowały ochronę dóbr niematerialnych hodowców na poziomie nie niższym niż wypracowane Konwencją standardy. Dopuszczalność kreowania rozwiązań korzystniejszych dla hodowców stanowić może o atrakcyjności prawodawstwa danego kraju członkowskiego Konwencji. ${ }^{8}$ Stanowi ona podstawę sui generis modelu ochrony wyłącznego prawa do odmian roślin.

Drugą kategorią przepisów międzynarodowych, na gruncie których istnieje, co najmniej teoretycznie, możliwość uzyskiwania ochrony praw niematerialnych do odmian roślin są: przyjęty w dniu 19 czerwca 1970 r. w Waszyngtonie Układ o współpracy patentowej ${ }^{9}$ oraz zawarta w dniu 5 października 1973 r. w Monachium Konwencja o patencie europejskim. ${ }^{10}$ Od samego początku jednak w toczących się dyskusjach gremiów naukowych i praktyków powstawały liczne wątpliwości w związku z możliwością udzielania patentu na nowe odmiany roślin, a mianowicie zastanawiano się, czy można udzielać ochrony patentowej organizmom żyjącym oraz w jaki sposób można precyzyjnie opisać rośliny czy też odmiany roślin, a także jak można odtworzyć w sposób szczegółowy sam proces prowadzący do otrzymania nowej odmiany. W niektórych porządkach prawnych udało się przezwyciężyć te trudności po dokonaniu pewnych modyfikacji, w krajach tych podejmuje się działania zmierzające do patentowania, jeśli nie nowych odmian roślin wprost, to czysto biologicznych metod ich hodowli.

\footnotetext{
6 http://www.upov.int/upovlex/en/conventions/1991/content.html

$7 \quad$ Z języka francuskiego Union pour la Protection des Obtentions Végétales.

8 Szerzej w przedmiocie genezy oraz zakresu stosowania Konwencji UPOV: M. Korzycka-Iwanow, P. Gała, Ochrona prawna odmian roślin, [w:] System prawa prywatnego, Tom 14a, Prawo własności przemysłowej, R. Skubisz (red.), Warszawa 2012, s. 985 i n.

$9 \quad$ Dz.U. z 1991 r. Nr 70, poz. 303 zał.

10 Dz.U. z 2004 r. Nr 79, poz. 737 ze zm.
} 
Zważywszy na przedstawione wyżej problemy, organizmy żywe w praktyce bardzo często uznawano jednak za nie nadające się do opatentowania. ${ }^{11}$ Europejskie organy patentowe odmawiały wynalazkom biologicznym technicznego charakteru, zaś w USA odmowę udzielenia patentu uzasadniano tym, że odmiany roślin stanowią produkt natury, nie zaś człowieka, niezależnie od tego, w jakim stopniu cechy odmiany stanowią rezultat ludzkich działań. ${ }^{12}$ Przytoczone wyżej względy zadecydowały, że na gruncie prawa międzynarodowego ${ }^{13}$ wyłączono odmiany roślin spod ochrony patentowej. Zgodnie $\mathrm{z}$ art. 53 Konwencji o patencie europejskim nie udziela się patentów europejskich m.in. na odmiany roślin albo rasy zwierząt lub czysto biologiczne sposoby hodowli roślin lub zwierząt.

Prawodawca międzynarodowy wypowiedział się ponadto w kwestii ochrony praw do odmian roślin w treści Porozumienia z dnia 15 kwietnia 1994 r. w sprawie handlowych aspektów praw własności intelektualnej ${ }^{14}$ (TRIPS ${ }^{15}$ ). Porozumienie to stanowiło załącznik do Porozumienia ustanawiającego Światową Organizację Handlu (WTO) zawartego 15 kwietnia 1994 r. w Marakeszu. ${ }^{16}$ Porozumienie TRIPS reguluje głównie obszar dotyczący prawa autorskiego, własności przemysłowej, a także ochrony informacji niejawnych oraz zapobieganiu praktykom antykonkurencyjnym. ${ }^{17}$ Ochronie odmian roślin poświęca tylko jeden przepis, ustalający swego rodzaju standard tej ochrony. Istotą tego rozwiązania jest relacja do zasady ochrony patentowej zawarta $\mathrm{w}$ art. 27 ust. 1, zgodnie z którą w ramach systemów prawnych podmiotów ratyfikujących Porozumienie, patenty będą udzielane na wszystkie wynalazki, produkty i procesy ze wszystkich dziedzin techniki, niezależnie od tego, czy dotyczą one produktu czy procesu, pod warunkiem, że są nowe, zawierają element wynalazczy i nadają się do przemysłowego stosowania. Od zasady tej przewidziano nieliczne wyjątki. W myśl regulacji art. 27 ust. 3 b), członkowie Porozumienia TRIPS, mogą wyłączyć ze zdolności patentowej:

„rośliny i zwierzęta inne niż drobnoustroje i zasadniczo biologiczne procesy służące do produkcji roślin i zwierząt inne niż procesy nie biologiczne i mikrobiologiczne. Jednakże Członkowie zapewnią ochronę dla odmian roślin albo patentami albo skutecznym systemem ochrony sui generis lub też kombinacją obu”.

Wspomniany wyżej „standard” ochrony odmian roślin wynikający z Porozumienia TRIPS polega zatem na niedopuszczalności pozostawienia odmian ro-

Szerzej H. Żakowska-Henzler, Wynalazek biotechnologiczny - przedmiot patentu, Warszawa 2006, s. 208.

Por. G. van Overwalle, Patent protection for plants: a comparison of American and European approaches, „IDEA: The Journal of Law and Technology" 1999, nr 39.

Uczyniono tak zarówno w ramach przyjętej w 1963 r. Konwencji strasburskiej (art. 2), jak i wspomnianej wcześniej Konwencji o patencie europejskim z 1973 r.

Dz.U. z 1996 r. Nr 32, poz. 143.

TRIPS od ang. Agreement on Trade Related Aspects of Intellectual Property Rights.

Dz.U. z 1995 r. Nr 98, poz. 483 zał. (z uzupełnieniem).

M. Korzycka-Iwanow, P. Gała, Ochrona prawna odmian roślin, op. cit., s. 999-1000. 
ślin uprawnych poza systemem ochrony dóbr niematerialnych ${ }^{18}$ (którymkolwiek ze wskazanych w art. 27 ust. $3 b$ ).

Na gruncie wskazanych wyżej regulacji międzynarodowych, tak w Polsce jak i w całej Unii Europejskiej ukształtował się, jako wyraźnie dominujący, sui generis model ochrony wyłącznego prawa do odmian roślin oparty na postanowieniach Konwencji UPOV.

W polskim porządku prawnym, podmiot uprawniony - hodowca odmiany rośliny może uzyskać dla tego dobra intelektualnego ochronę wyłącznego prawa w oparciu o dwie grupy przepisów: przepisy krajowe lub wspólnotowe. Na krajowy system ochrony wyłącznego prawa do odmiany składają się przepisy ustawy z dnia 26 czerwca 2003 r. o ochronie prawnej odmian roślin. ${ }^{19}$ Wspólnotowy system ochrony wyłącznego prawa do odmian roślin tworzą przepisy Rozporządzenia Rady (WE) nr 2100/94 z dnia 27 lipca 1994 r. w sprawie wspólnotowego systemu ochrony odmian roślin ${ }^{20}$ oraz jego przepisy wykonawcze. ${ }^{21}$ Wyłącznie od decyzji hodowcy zależy, w oparciu o który z ww. modeli ochrony uzyska on wyłączne prawo do odmiany. Obowiązujące przepisy uniemożliwiają jednak łączenie takiej ochrony. Tym samym dana odmiana rośliny może być chroniona wyłącznym prawem krajowym lub wspólnotowym, ale nigdy w ramach obydwu tych systemów. Brak jest zatem możliwości ich kolizji. ${ }^{22}$

Niezależnie od przyjętego systemu ochrony wyłącznego prawa do odmian roślin: krajowego czy też wspólnotowego, dowolna zbiorowość roślin wówczas stanowi odmianę w znaczeniu normatywnym, o ile charakteryzuje się odrębnością, wyrównaniem i trwałością. Cechy te stanowią zarazem przesłanki, jakim musi odpowiadać odmiana rośliny, aby jej hodowca mógł ubiegać się o przyznanie wyłącznego prawa (art. 4 ust. 1 ustawy o ochronie prawnej odmian roślin oraz art. 6 Rozporządzenia Rady (WE) nr 2100/94).

18 M. Korzycka-Iwanow, Hodowla roślin i nasiennictwo, [w:] Prawo rolne, A. Stelmachowski (red.), Warszawa 2005, s. 330.

19 Dz.U. z 2003 r. Nr 137, poz. 1300, ze zm.

20 Dz.Urz. WE L 227 z 1.09.1994 r., s. 1.

21 W szczególności: Rozporządzenie Komisji (WE) nr 1768/95 z dnia 24 lipca 1995 r. ustanawiające przepisy wykonawcze w zakresie odstępstwa rolnego przewidzianego w art. 14 ust. 3 rozporządzenia Rady (WE) nr 2100/94 w sprawie wspólnotowego systemu ochrony odmian roślin (Dz.U. L. 173 z dnia 25.07.1995 r., s. 14-21) oraz Rozporządzenie Komisji (WE) nr 2605/98 z dnia 3 grudnia 1998 r. zmieniające rozporządzenie (WE) nr 1768/95 ustanawiające przepisy wykonawcze $w$ zakresie odstępstwa rolnego przewidzianego $w$ art. 14 ust. 3 rozporządzenia Rady (WE) nr 2100/94 w sprawie wspólnotowego systemu ochrony odmian roślin (Dz.Urz. L. 328 z 4.12.1998 r., s. 6-7). M. Korzycka-Iwanow, P. Gała, Ochrona prawna odmian roślin, op. cit., s. 1000-1002. 


\section{Twórcza hodowla nowych odmian roślin a wymogi przepisów o ochronie bioróżnorodności}

Niezbędnym elementem twórczej hodowli nowych odmian roślin jest wykorzystywanie roślinnych zasobów genetycznych dla potrzeb krzyżowania różnych odmian roślin (czasem również gatunków) celem uzyskania nowych, pożądanych cech.

Zgodnie z postanowieniami art. 2 Traktatu o różnorodności biologicznej:

„«Zasoby genetyczne» - oznaczają materiał genetyczny posiadający faktyczną lub potencjalną wartość."

zaś

„«Materiał genetyczny» - oznacza jakikolwiek materiał roślinny, zwierzęcy, mikrobiologiczny lub innego pochodzenia, zawierający funkcjonalne jednostki dziedziczności."

Również Międzynarodowy traktat o zasobach genetycznych roślin dla wyżywienia i rolnictwa posługuje się zbliżonym pojęciem, a mianowicie pojęciem ,zasoby genetyczne roślin dla celów wyżywienia i rolnictwa”. Zgodnie ze słowniczkiem zawartym w art. 2 tego traktatu:

„«Zasoby genetyczne roślin dla celów wyżywienia i rolnictwa» oznaczają każdy materiał genetyczny pochodzenia roślinnego o faktycznej lub potencjalnej wartości dla celów wyżywienia i rolnictwa."

Definicje te są zatem niemal tożsame, o ile zwrócimy uwagę, że Międzynarodowy traktat o zasobach genetycznych roślin dla wyżywienia i rolnictwa koncentruje się wyłącznie na roślinnych zasobach genetycznych i to z przeznaczeniem na potrzeby wyżywienia oraz rolnictwa.

W twórczej hodowli nowych odmian roślin zazwyczaj źródłem materiałów genetycznych są kolekcje własne hodowcy oraz materiały genetyczne pochodzące od innych hodowców. Warto przy tym wskazać, że w systemie ochrony wyłącznego prawa do odmian roślin, nieograniczoną możliwość korzystania z cudzych zasobów genowych, zapewnia instytucja tzw. ,przywileju hodowcy”. Zgodnie z przepisami art. 22 ust. 3 pkt 3) ustawy o ochronie prawnej odmian roślin, wyłączne prawo do odmiany nie rozciąga się na jej materiał siewny, ani też materiał ze zbioru, o ile jest on przeznaczony "do tworzenia nowych odmian, z wyjątkiem odmian, o których mowa w ust. 1 pkt 3 , jeżeli odmiany te są wykorzystywane w celach zarobkowych."

Podobną regulację zawiera art. 15 ppk c) Rozporządzenia Rady (WR) nr 2100/94, zgodnie z którym: 
„Wspólnotowe prawa do ochrony odmian roślin nie obejmują działań podjętych w celu hodowli lub odkrycia i rozwijania innych odmian."

Wskazana wyżej regulacja prawna dopuszcza zatem bez żadnych ograniczeń możliwość korzystania z cudzych zasobów genowych dla potrzeb prowadzenia własnej, twórczej hodowli nowych odmian roślin.

Innymi źródłami zasobów genetycznych dla twórczej hodowli nowych odmian roślin są krajowe banki genów czy też Międzynarodowe Centra Badań Rolniczych, przy czym źródła te wykorzystywane są w Europie głównie przez uniwersytety, instytuty badawcze oraz mniejszych hodowców. ${ }^{23}$

Hodowcy wykorzystują różne typy zasobów genetycznych roślin w twórczej hodowli nowych odmian roślin. Hodowla nowych odmian roślin jest zazwyczaj oparta na wykorzystaniu zaawansowanego materiału genetycznego, ponieważ doprowadzenie mniej zaawansowanego materiału genetycznego do tych samych poziomów wydajności, jak nowa odmiana, jest bardzo pracochłonne. Głównym źródłem materiału genetycznego dla hodowców są nowoczesne odmiany roślin, choć stare odmiany i dzikie gatunki pokrewne mogą być wykorzystywane do wprowadzania pożądanych cech do populacji hodowlanych, w hodowli odpornościowej, czy dla wytwarzania odmian dostosowanych do mniej korzystnych warunków środowiskowych i niskonakładowych systemów produkcji. ${ }^{24}$

Obecnie, pozyskiwanie materiałów genetycznych przez hodowców dla potrzeb twórczej hodowli nowych odmian roślin odbywa się w ramach bezpośrednich kontaktów hodowców, w oparciu o zawierane przez nich umowy, często wysoce odformalizowane, a niejednokrotnie zawierane również $\mathrm{w}$ formie ustnej.

Powszechną praktyką jest także to, że ewentualny udział w korzyściach płynących z komercjalizacji wyłącznych praw do odmian roślin powstałych na skutek wymiany zasobów genetycznych określają właśnie takie dwustronne porozumienia. W przypadku zaś, gdy hodowca pozyskuje zasoby genowe, dla potrzeb swojej twórczej działalności hodowlanej, w inny sposób, np. poprzez badanie dostępnego w obrocie materiału siewnego innych odmian roślin (w tym chronionych wyłącznym prawem), czy też w drodze wyjazdów kolekcyjnych (np. do krajów ościennych), nie dzieli on uzyskanych z tego tytułu korzyści z żadnym innym podmiotem.

Na skutek przyjęcia przepisów Konwencji o różnorodności biologicznej, a przede wszystkim na skutek wejścia w życie regulacji Międzynarodowego traktatu

W. Podyma, Rośliny uprawne w rolnictwie i ogrodnictwie, leśnictwo. Ogrody botaniczne pod kątem wpływu wprowadzenia w Polsce nowych regulacji dotyczących dostępu do zasobów genetycznych i podziału korzyści wynikających z użytkowania tych zasobów (ABS) wynikających z postanowień Protokołu o dostępie do zasobów genetycznych oraz sprawiedliwym podziale korzyści wynikających z użytkowania tych zasobów (Protokołu z Nagoi) do Konwencji o różnorodności biologicznej, PAN Centrum Zachowania Różnorodności Biologicznej, s. 19, www. biodiv.gdos.gov.pl Ibidem, s. 10. 
o zasobach genetycznych roślin dla wyżywienia i rolnictwa oraz Protokołu z Nagoi do Konwencji o różnorodności biologicznej dotyczącego dostępu do zasobów genetycznych oraz uczciwego i sprawiedliwego podziału korzyści wynikających z ich wykorzystania, praktyka ta będzie musiała ulegać zmianie.

Przede wszystkim wskazać należy, że na gruncie Międzynarodowego traktatu o zasobach genetycznych roślin dla wyżywienia i rolnictwa ukształtowany został tzw. Wielostronny System Dostępu i Podziału Korzyści (część IV Konwencji). System ten statuuje udogodniony dostęp do zasobów genowych przy wykorzystaniu standardowej umowy transferu materiału genetycznego (sMTA). Stanowi on zatem swoistą platformę służącą do wymiany zasobów genetycznych zarówno pomiędzy umawiającymi się stronami, jak i pomiędzy hodowcami - czyli podmiotami sektora prywatnego. Przepisy art. 11 pkt 11.3 Konwencji wskazują bowiem, że:

„Umawiające się Strony postanawiają zastosować odpowiednie środki, celem zachęcenia osób fizycznych i jednostek prawnych pozostających w obrębie ich jurysdykcji oraz posiadających zasoby genetyczne roślin dla wyżywienia i rolnictwa, o których mowa w załączniku 1, do udostępnienia swoich zasobów genetycznych roślin dla celów wyżywienia i rolnictwa w ramach Wielostronnego Systemu."

Hodowcy, dokonujący dotychczas udostępnienia materiałów genetycznych z własnych zasobów, w drodze mniej lub bardziej sformalizowanych kontraktów dwustronnych, coraz częściej stosują ujednolicony i nieodpłatny system udostępniania takich zasobów w oparciu o sMTA.

Wydaje się zatem, że w przypadku stosowania przez hodowców Wielostronnego Systemu Dostępu i Podziału Korzyści nie będą oni objęci wymogami Protokołu z Nagoi. Zgodnie bowiem z przepisami art. 4 ust. 4 Protokołu z Nagoi:

„Niniejszy Protokół jest instrumentem wdrożeniowym postanowień Konwencji dotyczących dostępu i podziału korzyści. W przypadku, gdy mają zastosowanie specjalistyczne instrumenty dostępu i podziału korzyści, które są spójne, i nie są sprzeczne z celami Konwencji i z niniejszym Protokołem, niniejszy Protokół nie ma zastosowania dla Strony lub Stron tych specjalistycznych instrumentów, w zakresie określonych zasobów genetycznych objętych przez dany instrument i do jego celów."

Nie ulega zaś żadnej wątpliwości, że Wielostronny System Dostępu i Podziału Korzyści jest właśnie takim specjalistycznym instrumentem dostępu i podziału korzyści, spójnym z celami Konwencji o bioróżnorodności.

Nawet w takim przypadku, hodowcy pamiętać jednak muszą o postanowieniach art. 12 pkt 12.3 d) Międzynarodowego traktatu o zasobach genetycznych roślin dla wyżywienia i rolnictwa wskazującego, że: 
„osoby otrzymujące zasoby genetyczne nie mogą ubiegać się o przyznanie praw własności intelektualnej ani żadnych innych praw ograniczających ułatwiony dostęp do zasobów genetycznych roślin dla wyżywienia i rolnictwa, do ich części lub komponentów genetycznych, w formie otrzymanej z Systemu Wielostronnego."

Oczywiście kluczowym znaczeniem dla możliwości uzyskania przez hodowców korzystających z cudzych zasobów genetycznych będzie odnalezienie linii rozgraniczającej pomiędzy zasobem (lub komponentem) w formie otrzymanej z Systemu Wielostronnego a zasobem (komponentem) przetworzonym w procesie twórczej hodowli odmian roślin celem uzyskania nowej odmiany. Hodowcy nie będą mogli zatem występować z wnioskami o przyznanie wyłącznego prawa dla odmian roślin pozyskanych wprost z zasobów genetycznych pochodzących z Systemu Wielostronnego.

Inaczej będzie się jednak przedstawiała sytuacja w przypadku pozyskiwania przez hodowców zasobów genetycznych w oparciu o dotychczas utartą praktykę obrotu, tj. w drodze dwustronnych porozumień, często niesformalizowanych i nie opierających się na Wielostronnym Systemie Dostępu i Podziału Korzyści. W takim przypadku zastosowanie znajdą bowiem postanowienia art. 5 Konwencji z Nagoi oraz precyzujące go regulacje art. 4 Rozporządzenia Parlamentu Europejskiego i Rady (UE) nr 511/2014 statuujące wymóg, iż:

„Użytkownicy, dokładają należytej staranności, by upewnić się, czy wykorzystane przez nich zasoby genetyczne i tradycyjna wiedza związana z zasobami genetycznymi pozyskane były zgodnie z prawodawstwem lub przepisami krajowymi dotyczącymi dostępu i podziału korzyści oraz by korzyści były dzielone uczciwie i sprawiedliwie, zgodnie ze wzajemnie uzgodnionymi warunkami oraz zgodnie z wszelkimi mającymi zastosowanie wymogami prawa i przepisami."

Przepisy cytowanego wyżej art. 4 Rozporządzenia Parlamentu Europejskiego i Rady (UE) nr 511/2014 nakładają ponadto na hodowcę szereg wymogów proceduralnych związanych z pozyskiwaniem i gromadzeniem dokumentacji niezbędnej do wykazania, iż źródło wykorzystywanych przez hodowcę zasobów genetycznych jest legalne w rozumieniu przepisów Protokołu z Nagoi.

Konieczność pozyskiwania, gromadzenia oraz (we wskazanych przepisami przypadkach) legitymowania się właściwymi dokumentami będzie wywierała bezpośredni wpływ na procesy twórczej hodowli nowych odmian roślin poprzez ich wydłużenie oraz zwiększenie ich kosztów.

W jeszcze szerszym zakresie hodowcy zobligowani będą do wypracowania najlepszych praktyk oraz dokumentowania pozyskiwania zasobów genetycznych, a następnie uczciwego podziału korzyści płynących z tych zasobów w przypadku, gdy będą one pozyskiwane od społeczności tubylczych i lokalnych (art. 7 Protoko- 
łu z Nagoi oraz art. 4 ust. 2 Rozporządzenia Parlamentu Europejskiego i Rady (UE) nr 511/2014).

Niewątpliwie nałożony ww. przepisami obowiązek uczciwego i sprawiedliwego podziału korzyści płynących z wykorzystania zasobów genetycznych wpływał będzie na dochodowość hodowli twórczej nowych odmian roślin. Dotychczas w zakresie tym nie doszło do ukształtowania jakiejkolwiek praktyki. Wydaje się jednak, że kluczowymi problemami będzie:

- określenie, jaki musi być udział pozyskanych zasobów genetycznych jako komponentu przyszłej odmiany, aby w ogóle można było mówić o powstaniu po stronie hodowcy obowiązku podziału korzyści wynikających z zarobkowego korzystania z odmiany z dostarczycielem takich zasobów;

- określenie, jaka wartość udziału w korzyściach z zarobkowego korzystania z odmiany będzie nosić przymiot „uczciwego” i „sprawiedliwego” udziału w takich korzyściach.

Kwestie te będą musiały stać się w najbliższej przyszłości przedmiotem zainteresowania nie tylko hodowców, ale i doktryny prawa rolnego oraz prawa własności intelektualnej.

\section{Konkluzje}

Nie ulega wątpliwości, że nowe regulacje międzynarodowe dotyczące ochrony bioróżnorodności, a także zachowania roślinnych zasobów genowych dla wyżywienia i rolnictwa, a także regulacje wspólnotowe i krajowe, wdrażające te regulacje do wewnętrznych porządków prawnych krajów członkowski konwencji, wywierać będą istotny wpływ na ochronę dóbr intelektualnych w rolnictwie.

Wpływ ten wyrażał się będzie w wielu aspektach:

- po pierwsze, w niektórych przypadkach uniemożliwiał będzie w ogóle uzyskanie przez hodowcę wyłącznego prawa do odmian roślin, jeżeli odmiana ta zawierać będzie wystarczająco wiele ,nieprzetworzonych” komponentów pochodzących z zasobów genetycznych pozyskanych z obcych kolekcji;

- po drugie, proces twórczej hodowli nowych odmian roślin może ulegać spowolnieniu, a także koszt prowadzenia takiej hodowli może się zwiększyć, na skutek konieczności dokumentowania źródeł pochodzenia wykorzystywanych zasobów genetycznych, ich ewidencjonowania, dokumentowania ich transferu oraz kontroli;

- po trzecie, konieczne będzie wypracowanie modelu uczciwego i sprawiedliwego podziału korzyści związanych z zarobkowym korzystaniem z nowych 
odmian roślin wyhodowanych z udziałem zasobów genetycznych pochodzących ze źródeł obcych.

Niewątpliwie jednak regulacja taka jest potrzebna. Wydaje się, że może ona zapobiegać ,,rabunkowemu” wykorzystywaniu zasobów genetycznych krajów rozwijających się przez państwa rozwinięte lub też duże, międzynarodowe korporacje zajmujące się hodowlą twórczą nowych odmian roślin. Ponadto, zasoby uzyskane z takiego źródła mogą służyć ochronie naturalnych zasobów genetycznych przed ich erozją oraz powszechnym obecnie zanikaniem. 


\section{PROTECTION OF BIODIVERSITY \\ VIS INTELLECTUAL PROPERTY RIGHTS IN AGRICULTURE}

Keywords: biodiversity, breeding process, exclusive plant variety right

Convention on biological diversity of $5^{\text {th }}$ June, 1992 including the regulations of the "International Treaty" on Plant "Genetic Resources" for Food and Agriculture prepared in Rome on $3^{\text {rd }}$ November 2001 and the regulation of the Nagoya Protocol (of $29^{\text {th }}$ October 2010) on access to genetic resources and the fair and equitable sharing of benefits arising from their utilization to the Convention on biological diversity will significantly affect the practice relating to the creative breeding of new plant varieties. Among the objectives of the above cited international legal acts "the fair and equitable sharing of benefits derived from the utilisation of genetic resources" is to be noted. Since utilisation of genetic resources is an essential component of the creative breeding of new plant varieties, the new, detailed legal regulations covering this area have to cause impacts on the breeding process and obtaining the exclusive plant variety right. The new legal regulations concerning protection of biodiversity will impact, in particular, on far-reaching formalisation of the breeding process through enforcing compilation and collection of the documentation connected with the genetic resources of origin used in the breeding process. Moreover, the way of participation of particular seed industry participants in profits connected with commercialisation of the exclusive plant variety right will also be subject to remodelling. Beside hitherto beneficiaries of such profits, i.e. breeders (holders of the exclusive plant variety right) and seed companies (licensees of the exclusive plant variety right) the group of entities salary-earning for the exclusive plant variety right will be also extended with entities providing genetic resources for the creative needs of plant breeding. 